\title{
Effect of Particulates Generated from Asphalt Production on the Morphological and Leaf Epidermal Traits of some Common Plants
}

\author{
${ }^{* 1}$ AJURU, MERCY GOSPEL ${ }^{1}$ FRIDAY, UPADHI ${ }^{2}$
}

\author{
${ }^{I}$ Department of Plant Science and Biotechnology, Faculty of Science, Rivers State University of Science and Technology, Oroworukwo, P. \\ M. B. 5080, Port Harcourt, Rivers State, Nigeria; ${ }^{2}$ Department of Biology, Faculty of Pure and Applied Sciences, Ignatius Ajuru University \\ of Education, Rumuolumeni, P.M.B 5047, Port Harcourt, Rivers State, Nigeria. \\ Corresponding email: ajurumercygospel@yahoo.com
}

\begin{abstract}
A comparative study was carried out to ascertain the effects of particulate matter on the gross morphological and leaf epidermal features of some tropical plants. Two populations of Xanthosoma mafaffa Schott, Chromolaena odorata (L.) King and Robinson, and Ageratum conyzoides (L.) were collected; one from an unpolluted area and the other from a polluted environment (generated from an asphalt production industry). Plants from the polluted area show marked reduction in leaf size and area, and reduced chlorophyll content in leaves. There were chlorotic and necrotic leaf spots on the species from polluted area and an average leaf area of $94.81 \mathrm{~cm}^{2}, 15.81 \mathrm{~cm}^{2}$, and $17.29 \mathrm{~cm} 2$ for X. mafaffa, C. odorata and A. conyzoides respectively while the non-polluted species had no leaf spots and an average leaf area of $181.95 \mathrm{~cm}^{2}, 36.75 \mathrm{~cm}^{2}$, and $32.11 \mathrm{~cm}^{2}$ for X. mafaffa, C. odorata and A. conyzoides respectively. Length and width of stomatal pore of leaves from polluted area had increased number of stomata, but the length and width of stomata were reduced by $-12.89 \%$ and $08.42 \%,-19.54 \%$ and $-28.60 \%$ and $-27.50 \%$ and $-37.86 \%$ in the length and width of $X$. mafaffa, $C$. odorata and A. conyzoides respectively, as compared to the leaf samples from unpolluted area. Also, epidermal cells decreased compared to the leaves from unpolluted area, while the density of epidermal cells per unit area increased. These suggest that these plants are under air pollution stress and the results are adaptive and compensated mechanism to the adverse effects of the particulate matter. (C) JASEM
\end{abstract}

\section{http://dx.doi.org/10.4314/jasem.v20i2.23}

\section{Introduction}

Particulate matter (PM) is the term for particles found in air, including dust, soot, dirt, smoke and liquid droplets. Particulate matter is of localized importance near roads, cement works, and other industrial areas. Apart from screening out sunlight, dust on leaf blocks stomata and lowers their conductants to Carbon iv oxide (Jitin and Manish, 2014). Asphalt, which is also referred to as bitumen, is a form of petroleum that is sticky, black and highly viscous. It is primarily used as the glue or binder mixed with aggregate particles to produce asphalt concrete which is used for road construction. Asphalt is composed majorly of naphthene and polar aromatics. Other components are saturates and asphaltenes.

The major problem in modern society is air pollution. Air pollution is made up of various gases and minute particles that cause harm to plants, animals, humans, and also damage the environment. It is an environmental stress that limits plant productivity and survival (Woo, et al; 2007). It arises from industrialization which is a major threat to the environment. Air pollution deteriorates ecological condition and can be defined as the fluctuation in any atmospheric constituent from the value that would have existed without human activity (Tripathi and Gautam, 2007). Air pollutants, responsible for plant injury and losses in crop yield, are of increasing concern (Joshi and Swami, 2007). Much research work has been carried out on the effect of air pollutants on vegetation at various levels, and it has been observed that sulphur and nitrogen oxides concentrations are higher at urban sites (Tiwari, et al; 2006).

Asphalt in the soil can increase the soil $\mathrm{pH}$ to levels adverse to crop growth, as it could denature the enzymes showing visible morphological signs as torn margins of leaves, twisted stems, retarded trunk, reduced fruit size, reduce root extension system etc. Asphalt can cause leaf injury, stomatal damage, premature senescence, decrease photosynthetic activity, disturb membrane permeability and reduce growth and yield in sensitive plant species.

\section{MATERIALS AND METHODS}

For morphological and leaf epidermal analysis, whole plants and matured leaf samples of Xanthosoma mafaffa (New cocoyam), Chromolaena odorata (Siam 
weed) and Ageratum conyzoides (Goat weed) were randomly collected in October - December, 2015, from Usua farm land surrounding an Asphalt Generating Plant owned by $\mathrm{H}$ x $\mathrm{H}$ Engineering in Mbiama, along the East West Road, Ahoada-West Local Government Area, and Ignatius Ajuru University of Education main campus, situated at Rumuolumeni, Port Harcourt, Rivers State, Nigeria. The Asphalt generating Plant produces asphalt and releases lots of particulate matter (black soot) that lay thickly on the surfaces of all the plants found in the farmland.

The population from the Usua farmland represented a polluted site in which plants were affected by air pollutants from the asphalt generated from the Plant while the population from the main campus of Ignatius Ajuru University of Education was devoid of these pollutants and represents a non-polluted site.

For morphological study, ten leaves per population were measured for their sizes and the leaf areas with the help of thread and measuring scale. Leaf width was measured in upper, middle and lower part and average of three was taken as final width. The general coloration of the leaves was noted.

The epidermal peels for epidermal studies were obtained as follows: The leaves were placed with the outer surface facing downward on a flat surface and flooded with commercial bleaching agent. The epidermis was gently and carefully peeled off from the mesophyll tissues of the leaves with the aid of sharp razor blade. The peels were stained with safranin and mounted temporarily on slides. Ten slides (each of adaxial and abaxial surfaces) were prepared per population. These slides were examined under the light microscope and data were collected from 10 microscopic fields selected at random from each slide. The length and width of stomatal pores, guard cells, and epidermal cells were measured in $\mu \mathrm{m}$ with ocular micrometer under high power magnifications with the help of "Stage-Ocular micrometry". Number of stomata and epidermal cells were counted per square millimeter area, and stomatal index were determined. Data were analyzed statistically.

\section{RESULTS AND DISCUSSION}

Data on leaf size and area, and general leaf coloration of X. mafaffa, C. odorata and A. conyzoides, collected are presented in Table 1. The polluted population of this species had leaf chlorosis and necrotic spots and average leaf area of $94.81 \mathrm{~cm}^{2}, 15.81 \mathrm{~cm}^{2}$, and 17.29 cm2 for X. mafaffa, C. odorata and A. conyzoides respectively while that of the non-polluted population had an average leaf area of $181.95 \mathrm{~cm}^{2}, 36.75 \mathrm{~cm}^{2}$, and
$32.11 \mathrm{~cm}^{2}$ for $X$. mafaffa, C. odorata and A. conyzoides respectively. No necrotic spots were observed on the surfaces of the leaves found in the unpolluted site. The natural dark green colour of leaves of the polluted population had faded compared to those of the nonpolluted population.

Table 1: Average length $(\mathrm{cm})$, width $(\mathrm{cm})$ and area $\left(\mathrm{cm}^{2}\right)$ of leaves of X. mafaffa, C. odorata and $A$. conyzoides growing at polluted and unpolluted sites.

\begin{tabular}{|c|c|c|c|}
\hline X. mafaffa & $\begin{array}{l}\text { Polluted } \\
\text { site }\end{array}$ & $\begin{array}{l}\text { Unpolluted } \\
\text { site }\end{array}$ & $\begin{array}{l}\text { DFC } \\
(\%)\end{array}$ \\
\hline $\begin{array}{l}\text { Length } \\
(\mathrm{cm})\end{array}$ & $11.22 \pm 3.3$ & $15.05 \pm 2.0$ & $(-) 34.14$ \\
\hline Width (cm) & $08.45 \pm 3.2$ & $12.09 \pm 3.2$ & $(-) 43.07$ \\
\hline Area $\left(\mathrm{cm}^{2}\right)$ & $94.81 \pm 0.4$ & $181.95 \pm 2.3$ & $(-) 91.91$ \\
\hline C. odorata & & & \\
\hline $\begin{array}{l}\text { Length } \\
(\mathrm{cm})\end{array}$ & $05.02 \pm 1.3$ & $07.15 \pm 2.2$ & $(-) 42.43$ \\
\hline Width (cm) & $03.15 \pm 5.8$ & $05.14 \pm 0.2$ & $(-) 63.17$ \\
\hline Area $\left(\mathrm{cm}^{2}\right)$ & $15.81 \pm 3.6$ & $36.75 \pm 1.6$ & $\begin{array}{l}(- \\
) 132.44\end{array}$ \\
\hline $\begin{array}{l}\text { A. } \\
\text { conyzoides }\end{array}$ & & & \\
\hline $\begin{array}{l}\text { Length } \\
(\mathrm{cm})\end{array}$ & $05.02 \pm 1.4$ & $06.62 \pm 2.4$ & $(-) 31.87$ \\
\hline Width $(\mathrm{cm})$ & $03.45 \pm 1.8$ & $04.85 \pm 3.8$ & $(-) 40.57$ \\
\hline Area $\left(\mathrm{cm}^{2}\right)$ & $17.29 \pm 1.3$ & $32.11 \pm 1.7$ & $(-) 85.71$ \\
\hline
\end{tabular}

$\mathrm{DFC}=$ Difference from unpolluted site

Observations on length, width and number of epidermal cells of $X$. mafaffa, $C$. odorata and $A$. conyzoides growing at polluted and unpolluted areas are presented in Table 2 . There was marked alteration in epidermal features, with increased number of epidermal cells per square millimeter on both the adaxial and abaxial surfaces of leaves at polluted area, as compared to unpolluted area in all the species studied. The increased in number was $28.91 \%, 31.44 \%$ and16.60 on the adaxial surfaces of X. mafaffa, $C$. odorata and $A$. conyzoides respectively, and $34.70 \%$, $30.56 \%$ and $26.79 \%$ on the abaxial surfaces of $X$. mafaffa, $C$. odorata and $A$. conyzoides respectively. There was reduction of epidermal length and width in the adaxial and abaxial surfaces of leaves at polluted area, as compared to the increased in epidermal cell length and width of leaves at unpolluted area. This reduction in cell length was 13.44 and $16.21 \%, 04.03$ and $04.14 \%$, and 05.44 and $17.19 \%$ for adaxial and abaxial surfaces of X. mafaffa, $C$. odorata and $A$. conyzoides respectively. The reduction in cell width was 02.59 and $03.72 \%, 07.17$ and $12.01 \%$ and 19.58 and $25.02 \%$ for adaxial and abaxial surfaces of $X$. mafaffa, $C$. odorata and $A$. conyzoides respectively. 
Full-text Available Online at www.ajol.info and www.bioline.org.br/ja
J. Appl. Sci. Environ. Manage. March., 2016

Vol. 20 (1) $403-406$

Table 2: Average number (per $\mathrm{mm}^{2}$ ), length $(\mu \mathrm{m})$ and width $(\mu \mathrm{m})$ of epidermal cells in leaves of $X$. mafaffa, $C$. odorata and A. conyzoides growing at polluted and unpolluted sites.

\begin{tabular}{|c|c|c|c|c|}
\hline X. mafaffa & Leaf surface & Polluted site & Unpolluted site & $\mathrm{DFC}(\%)$ \\
\hline \multirow[t]{2}{*}{ Number } & Adaxial & $1233.12 \pm 2.21$ & $876.56 \pm 2.33$ & $(+) 28.91$ \\
\hline & Abaxial & $1034.43 \pm 3.50$ & $675.45 \pm 1.67$ & $(+) 34.70$ \\
\hline \multirow[t]{2}{*}{ Length $(\mu \mathrm{m})$} & Adaxial & $32.32 \pm 0.12$ & $37.56 \pm 0.14$ & $(-) 16.21$ \\
\hline & Abaxial & $32.13+0.11$ & $36.45+0.13$ & $(-) 13.44$ \\
\hline \multirow[t]{2}{*}{ Width $(\mu \mathrm{m})$} & Adaxial & $23.54 \pm 0.05$ & $24.15 \pm 0.03$ & $(-) 02.59$ \\
\hline & Abaxial & $21.76 \pm 0.04$ & $22.57 \pm 0.07$ & $(-) 03.72$ \\
\hline \multicolumn{5}{|l|}{ C. odorata } \\
\hline \multirow[t]{2}{*}{ Number } & Adaxial & $956.09 \pm 4.23$ & $655.44 \pm 3.02$ & $(+) 31.44$ \\
\hline & Abaxial & $913.44 \pm 3.22$ & $634.23 \pm 2.97$ & $(+) 30.56$ \\
\hline \multirow[t]{2}{*}{ Length $(\mu \mathrm{m})$} & Adaxial & $24.05 \pm 0.09$ & $25.02 \pm 0.05$ & $(-) 04.03$ \\
\hline & Abaxial & $21.21 \pm 0.08$ & $22.09 \pm 0.08$ & $(-) 04.14$ \\
\hline \multirow[t]{2}{*}{ Width $(\mu \mathrm{m})$} & Adaxial & $22.05 \pm 0.02$ & $24.70 \pm 0.03$ & $(-) 12.01$ \\
\hline & Abaxial & $21.04 \pm 0.02$ & $22.55 \pm 0.04$ & $(-) 07.17$ \\
\hline \multicolumn{5}{|l|}{ A. conyzoides } \\
\hline \multirow[t]{2}{*}{ Number } & Adaxial & $906.12 \pm 3.09$ & $755.65 \pm 3.02$ & $(+) 16.60$ \\
\hline & Abaxial & $895.32 \pm 2.98$ & $655.43 \pm 2.93$ & $(+) 26.79$ \\
\hline \multirow{2}{*}{ Length $(\mu \mathrm{m})$} & Adaxial & $21.05 \pm 0.02$ & $24.67 \pm 0.05$ & $(-) 17.19$ \\
\hline & Abaxial & $20.95 \pm 0.07$ & $22.09 \pm 0.07$ & $(-) 05.44$ \\
\hline \multirow[t]{2}{*}{ Width $(\mu \mathrm{m})$} & Adaxial & $18.05 \pm 0.02$ & $22.60 \pm 0.05$ & $(-) 25.20$ \\
\hline & Abaxial & $17.05 \pm 0.06$ & $20.39 \pm 0.04$ & $(-) 19.58$ \\
\hline
\end{tabular}

$\mathrm{DFC}=$ Difference from unpolluted site

X. mafaffa is amphistomatic, that is, stomata are found on both the adaxial and abaxial surfaces, while $C$. odorata and A. conyzoides are hypostomatic, that is, having stomata only on the abaxial surface. Table 3 shows average number of stomata, length and width of stomata of leaf samples collected from polluted and unpolluted areas. Results showed that leaves from polluted area had increased number of stomata, but the length and width of stomata were reduced by $-12.89 \%$ and $-08.42 \%,-19.54 \%$ and $-28.60 \%$ and $-27.50 \%$ and $-37.86 \%$ in the length and width of $X$. mafaffa, $C$. odorata and A. conyzoides respectively, as compared to the leaf samples from unpolluted area. A number of closed stomatal apertures and distorted stomata were observed on the leaf samples of all the species from polluted area

Table 3: Average number of stomata (per $\left.\mathrm{mm}^{2}\right)$, length and width of guard cells $(\mu \mathrm{m})$ on abaxial surfaces of leaves of $X$. mafaffa, $C$. odorata and A. conyzoides growing at polluted and unpolluted sites

\begin{tabular}{|l|l|l|l|}
\hline X. mafaffa & Polluted site & Unpolluted site & DFC (\%) \\
\hline Number & $141.19 \pm 3.04$ (Adaxial) & $119.21 \pm 2.72$ & $(+) 15.56$ \\
& $156.23 \pm 2.23$ (Abaxial) & $125.16 \pm 3.45$ & \\
\cline { 2 - 4 } & & & $(-) 19.88$ \\
\hline Length $(\mu \mathrm{m})$ & $22.34 \pm 0.07$ & $25.22 \pm 1.08$ & $(-) 08.89$ \\
\hline Width $(\mu \mathrm{m})$ & $10.56 \pm 0.03$ & $11.45 \pm 0.02$ & \\
\hline C. odorata & & & $(+) 32.66$ \\
\hline Number & $122.25 \pm 3.32$ & $82.32 \pm 1.02$ & $(-) 19.54$ \\
\hline Length $(\mu \mathrm{m})$ & $19.34 \pm 0.03$ & $23.12 \pm 1.21$ & $(-) 28.60$ \\
\hline Width $(\mu \mathrm{m})$ & $11.64 \pm 0.01$ & $14.97 \pm 0.03$ & \\
\hline A. conyzoides & & & $(+) 34.74$ \\
\hline Number & $122.09 \pm 2.56$ & $79.67 \pm 1.03$ & $(-) 27.50$ \\
\hline Length $(\mu \mathrm{m})$ & $17.45 \pm 0.04$ & $22.25 \pm 1.32$ & $(-) 37.86$ \\
\hline Width $(\mu \mathrm{m})$ & $10.14 \pm 0.01$ & $13.98 \pm 0.07$ & \\
\hline
\end{tabular}

DFC Difference from unpolluted site

The reduced growth in size, development of necrosis and colour-fading appearance of leaves of all the species studied and growing in the polluted environment could be due to the blockage of stomatal aperture occasioned by the effects of particulate matter derived from the asphalt products from the industry. This could also reduce the photosynthetic capacity of these leaves. The loss of green colouration in leaves of 
this population might hinder food-manufacturing ability of the leaves whose stomatal apertures were also closed.

The large, healthy green leaves and opened stomatal apertures of the non polluted populations of theses taxa could be a positive response to equable conditions they derived from steady and less disturbed microhabitat. It is believed that the healthy leaves of these species are able to capture enough sunlight for photosynthesis, since there are no dust particles obstructing the direct rays of sunlight on the leaves. This no doubt enhances other metabolic processes that encourage growth in the plants.

Increased number of stomatal and epidermal cells on the surfaces of leaves of the polluted population could be a physiological development by the species to survive the unfriendly environmental conditions created by the high rate of pollution in the area, thus confirming the previous assertion of Pal et al. (2002) on stomatal frequency. This also supports findings from other workers (Sharma and Roy, 1995, Pal et al; 2000, Aggarwal, 2000; and Rai and Kulshreshtha, 2006). The reduction in size of stomatal and epidermal cells in the polluted species conforms to other works (Sharma and Roy, 1995; Aggarwal, 2000; Kaur, 2004; Dineva, 2006; Rai and Kushreshtha, 2006). The reduction in the size of stomata and epidermal cells may be an adaptive response of these species to prevent the entry of harmful constituents of the asphalt particulate matter which is detrimental to the survival of the plants. Distorted stomatal shapes observed in leaf samples collected from polluted area may be due reduction in the turgidity of the guard cells and physiological injury inside the leaves.

The results from this study showed that the morphological and epidermal characters in plant species growing in asphalt polluted environment are considerably affected and modified due to the deposition of the particulate matter on them. This variation may be taken as indicator of environmental stress experienced by plants.

\section{REFERENCES}

Aggarwal, P (2000). The effect of auto-exhaust pollution on leaf surface of Cassia siamea (L.), a road side tree. Acta Ecologica 22: 101-106

Dineva, S (2006). Development of leaf blades of Acer platanoides in industrially contaminated environment. Dendrobiology 55: 25-32.

Jitin, R; Manish, KJ (2014). An Investigation into the Impact of Particulate Matter on Vegetation along the National Highway: A Review. Research Journal of Environmental Sciences, 8: 356-372.

Joshi, PC; Swami, A (2007). Physiological responses of some tree species under roadside automobile pollution stress around city of Haridwar, India. Environmentalist, 27: 365-374.

Kaur, S (2004). Stomatal responses of lemon (Citrus medica) to exhaust emissions from vehicles using different types of fuel. Pollution Research 23(3):451-454.

Pal, A., Kulshreshtha, K., Ahmad, KJ; Yunus, M (2000). Changes in leaf surface structures of two avenue tree species caused by auto exhaust pollution. Journal of Environmental Biology 21 (1): 15-21.

Pal, AK; Kulshreshtha, K; Ahmad, KJ; Behl, HM (2002). Do leaf surface characters play a role in plant resistance to auto-exhaust pollution? Flora Morphol. Distrib. Funct. Ecol. Plants, 197: 47-55.

Rai, A., Kulshreshtha, K (2006). Effect of particulates generated from automobile emission on some common plants. Journal of food, Agriculture and Environment 4(1): 253-259.

Sharma, M; Roy, AN (1995). Effect of automobile exhaust on the leaf epidermal features of Azadirachta indica and Dalbergia sissoo. Int. Journal of Mendel 12(1-4): 18-19.

Tiwari, S; Agrawal, M; Marshall, FM (2006). Evaluation of ambient air pollution impact on carrot plants at a sub urban site using open top chambers. Environ. Monit. Assess., 119: 15-30.

Tripathi, AK; Gautam, M (2007). Biochemical parameters of plants as indicators of air pollution. J. Environ. Biol; 28: 127-132.

Woo, SY., Lee, DK; Lee, YK (2007). Net photosynthetic rate, ascorbate peroxidase and glutathione reductase activities of Erithrina orientalis in polluted and non-polluted areas. Photosynthetica, 45: 293-295. 